Pamiętnik Literacki 2017, 4, s. 41-48

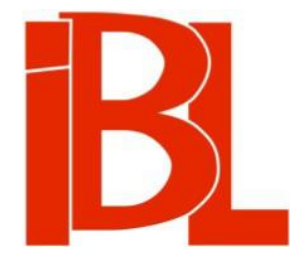

\title{
Leszka Kołakowskiego eksperymenty z Beckettem
}

Żaneta Nalewajk 
Pamiętnik Literacki CVIII, 2017, z. 4, PL ISSN 0031-0514

DOI: $10.18318 / \mathrm{pl} .2017 .4 .3$

ŻANETA NALEWAJK Uniwersytet Warszawski

\section{LESZKA KOŁAKOWSKIEGO EKSPERYMENTY Z BECKETTEM}

W utworze scenicznym System księdza Jensena, albo Wejście i wyjście. Farsa $w 2$ aktach naśladowana $z$ różnych autorów, nieoryginalna. Polemika optymistyczna z Beckettem, opublikowanym pierwotnie w 1965 roku na łamach numeru 6 „Dialogu" ${ }^{1}$, polski filozof i pisarz Leszek Kołakowski, nawiązując do spuścizny literackiej irlandzkiego autora ${ }^{2}$ i eksperymentując $\mathrm{z}$ nią, przywołał najważniejsze bodaj dla Becketta kategorie temporalne, takie jak oczekiwanie, niedokonanie, powtórzenie, nuda i zmiana ${ }^{3}$, które powracały niemal we wszystkich dziełach dramaturga, a najpełniej doszły do głosu w sztuce Czekajac na Godota (1948) oraz w napisanym ponad dekadę wcześniej eseju zatytułowanym Proust (1931).

Na istotność nawiązań do dzieł irlandzkiego twórcy, a zarazem na ważkość problematyki czasu wskazuje już podtytuł tekstu Kołakowskiego: Polemika optymistyczna z Beckettem. Będący komponentem tego sformułowania epitet „optymistyczny" jest ukierunkowany temporalnie i ma charakter wieloznaczny. W sensie słownikowym „optymistyczny” to przecież nie tylko 'zakładajacy pozytywny obrót spraw w przyszłości', lecz także wiążący się z poglądem filozoficznym, według którego istniejący świat został racjonalnie urządzony i jawi się jako najlepszy z możliwych, a skoro jest najlepszy $\mathrm{z}$ możliwych, to życie w nim też musi być dobre.

1 Utwór przedrukowany został w tomie: L. Koła k ow s ki, Pochwała niekonsekwencji. Pisma rozproszone z lat 1955-1968. Przedm., wybór, oprac. Z. M e n tz el. T. 3. Warszawa 1989, s. 115-135. Wszystkie cytowane w tekście fragmenty przywołuję według tego wydania. Oznaczam je skrótem KS. Ponadto stosuję skróty: BC = S. B e c k e t t, Czekając na Godota. Przeł. A. Li b e r a. Oprac. W. Błoński. Warszawa 1992. - BE = S. Beckett, En attendant Godot. Paris 1952. - BW = S. Beckett, Waiting for Godot. A Tragicomedy in Two Acts. London-Boston 1948. Liczby po skrótach wskazują stronice.

2 Wzmianki na ten temat odnaleźć można w książce M. M i c hals k i e g o Filozofjako pisarz. Kołakowski - Skarga - Tischner (Gdańsk 2010).

3 Szerzej pisałam o tym w tekście Postaci czasu - czas postaci. Kategorie temporalne $w$ wybranych utworach Samuela Becketta („Tekstualia” 2010, nr 1). Zob. też H. P. A b b o t: The Fiction of Samuel Beckett: Form and Effect. Berkeley 1973; Beckett Writing Beckett: The Author in the Autograph. Ithaca 1996. - Samuel Beckett: Humanistic Perspectives. Ed. M. Beja, S. E. Gontarski, P. Astier. Ohio 1983. - J. C ald er, The Philosophy of Samuel Beckett. London 2001. T. W iśn i ew s ki, Kształt literacki dramatu Samuela Becketta. Kraków 2006. - Samuel Beckett. Tradycja - awangarda. Red. T. Wiśniewski. Sopot 2012. - Back to the Beckett Text. Red. T. W i śn n e w s ki. Gdańsk-Sopot 2012. - S. E. G o n t a r s k i, Beckett Matters: Essays on Beckett's Late Modernism. Edinburgh 2016; a ponadto wspomniane wydanie monograficzne kwartalnika „Tekstualia” (2010, nr 1) i inne. 
Zarówno potoczne, jak i przystające do tradycji filozoficznej rozumienie tego słowa zyskuje w dziele scenicznym Kołakowskiego reprezentację ukazana zgodnie $z$ regułami farsy, czyli utworu komediowego, którego łatwowierni bohaterowie coraz bardziej zapętlają się w niewygodnej dla nich sytuacji.

Pierwsze $z$ ujęć optymizmu znajduje swoje odzwierciedlenie w konstrukcjach postaci Emeryta, Doktora, Starszej Pani i Ewy, cechujących się ufnym nastawieniem w stosunku do przyszłych wydarzeń oraz - jak w wypadku tej ostatniej bohaterki - reagujacych na myśl o nich entuzjastycznie i w sposób egzaltowany, pomimo przeraźliwych krzyków dobiegających zza drzwi gabinetu, do którego wszyscy chcieliby jak najszybciej wejść. Optymistyczne usposobienie w drugim (Leibnizowskim z ducha) znaczeniu uosabia natomiast ksiądz Jensen, który, głosząc apoteozę logiki, jest w stanie uzasadnić - m.in. przy użyciu sylogizmów, argumentacji przez przykład i wyliczenie oraz amplifikacji - nie tylko trwające dekady oczekiwanie, lecz także nawet najbardziej niespodziewane i absurdalne zajścia. Rozpatrywana w tym świetle, fraza podtytułu „polemika optymistyczna z Beckettem” ujawnia zatem w pełni swój ironiczny charakter.

Analizowane na płaszczyźnie poetologicznej dzieła Becketta i Kołakowskiego mają wiele cech wspólnych. Zbliża je do siebie potencjalna dwuplanowość znaczeniowa, w której sens nie tylko jest stanowiony na poziomie literalnym, lecz także może konstytuować się na płaszczyźnie parabolicznej, kształtowanej dzięki zastosowaniu niedopowiedzenia, sprzyjającego kreowaniu efektu polisemiczności oraz wkomponowywaniu licznych aluzji do tradycji staro- i nowotestamentowej. W dziele irlandzkiego autora odnajdziemy np. nawiązania do historii o dwóch złoczyńcach powieszonych obok Chrystusa na krzyżu, znanej z Ewangelii ${ }^{4}$, napotkamy tu także odwołania do opowieści o Kainie i Ablu (BC 118), wzmianki o postaciach biblijnych, takich jak Adam (BC 69) ${ }^{5}$ i Jezus (BC 86), odniesienia do Księgi Ezechiela $(34,17)$ i Ewangelii św. Mateusza (25, 32-33) czy do idei zbawienia (BC 107). Z kolei w utworze Kołakowskiego pojawia się m.in. aluzja do fragmentu starotestamentowej 1 Księgi Samuela $(16,7)$, zgodnie z którym „Człowiek patrzy na wygląd, Jahwe czyta w sercu”. Nawiązuje się tu także pośrednio do wpisanego w to stwierdzenie założenia, że Bóg interesuje się ludzkimi sprawami, że los człowieka nie jest Mu obojętny.

Wspomniane odwołania do źródeł zostały jednak potraktowane przez autorów

4 W Ewangelii św. Łukasza czytamy: „A kiedy przyszli na miejsce zwane Czaszką, ukrzyżowali Jego i dwu złoczyńców” (Łk 23, 33, 39. Ten i dalsze cytaty biblijne pochodzą z wydania: Pismo Święte Starego i Nowego Testamentu. Biblia prasko-warszawska. Przeł. z języków oryginalnych i oprac. K. Romaniuk. Wyd. 2, popr. Warszawa 1998). O złoczyńcach pisze także św. Mateusz: „Wtedy ukrzyżowano wspólnie z nim dwóch złoczyńców, jednego po prawej, drugiego po lewej” (Mt 27, 38). Natomiast ś w. J a n w ogóle nie wspomina o dwóch złoczyńcach, mówi jedynie o „dwóch innych ludziach” (J 19, 17); św. Ma te u s z, stwierdza, że nawet złoczyńcy „złorzeczyli” Jezusowi (Mt 27, 38, 44), z kolei św. Ma r e k pisze: „Ubliżali Mu nawet Ci, którzy byli razem z Nim ukrzyżowani” (Mk 15, 27, 32). Odniesienie do tej niespójności relacji pojawia się w tekście B e cketta np. w kwestii Vladimira: „Dlaczego [...] spośród czterech Ewangelistów tylko jeden o tym wspomina. Przecież byli tam wszyscy czterej - tam albo gdzieś w pobliżu. A o zbawionym łotrze mówi tylko jeden" (BC 43).

5 Wspomniana aluzja występuje wyłącznie w wersji anglojęzycznej tekstu, w wariancie francuskim ten antroponim zastapiony został imieniem Catullus. 
omawianych tekstów w dość dowolny sposób. Podlegaja one nierzadko daleko idącym przekształceniom, które nadają im charakter polisemiczny. Dla przykładu, Beckettowski Godot, którego przyjście identyfikowane jest przez bohaterów $z$ szansą na zbawienie, da się w pełni utożsamić $\mathrm{z}$ Bogiem tylko w rezultacie interpretacji ujednoznaczniającej ${ }^{6}$. Nie sposób bowiem przeoczyć, że w tekście wspomina się o Stwórcy niezależnie od postaci Godota. Po uważnej lekturze nasuwa się zatem wniosek, że ów enigmatyczny antroponim może, ale nie musi być odczytywany parabolicznie, jako Boski przydomek. $Z$ analogiczną dwuznacznością, a zarazem nierozstrzygalnością semantyczną mamy do czynienia w farsie polskiego filozofa. Kołakowski wykreował w niej postać dyrektora na wzór i podobieństwo Stwórcy, który, choć nieobecny - w przekonaniu większości bohaterów - czuwa nad zachowaniem sprawiedliwości i ładu, ,interesuje się [...] [ludzkimi - Ż. N.] sprawami”, „wgląda” i „wnika w nie głęboko” (KS 121). Ta postać nie jest jednak nazywana Bogiem, podobnie jak nie określa się tym mianem nieobecnego dentysty, do którego przychodzą niezliczeni pacjenci w nadziei, że pozbędą się swoich bolączek egzystencjalnych. Najważniejszy bodaj rezultat tego, że omawiani autorzy zastosowali rozwiązania mające na celu wykreowanie efektu wieloznaczności, stanowi możliwość odczytania - kluczowej dla obu tekstów - figury oczekiwania nie tylko w sposób dosłowny, lecz także jako przejawu metafizycznych dyspozycji postaci.

Wspólna dla tych twórców jest także predylekcja do parodiowania i/lub trawestowania poglądów znanych filozofów. Odcisnęła ona swoje piętno na każdym z analizowanych dzieł. Przykładowo, Vladimir i Estragon, czekając na Godota, dokonuja trawestacji słynnego Heraklitejskiego stwierdzenia: „Niepodobna wstapić dwukrotnie do tej samej rzeki”, które po przeróbce stylistycznej zyskuje taki oto kształt: „Nie wchodzi się nigdy dwa razy w to samo gówno” (BC 83) / „On ne descend pas deux fois dans le même pus” (BE 84) / "It's never the same pus from one second to the next" (BW 60). Z kolei poirytowani nie kończacym się oczekiwaniem bohaterowie utworu Kołakowskiego, ignorując przez dłuższy czas to, że nikt spośród tych, którzy weszli do gabinetu stomatologicznego, nie wrócił po zabiegu do poczekalni, prowadzą $z$ księdzem Jensenem dysputy na temat zasad sprawiedliwego porządku społecznego.

W replikach dialogowych wielokrotnie dochodzi do głosu parodia stanowisk filozoficznych $w$ tej i wielu innych kwestiach. Jej ostrze dosięga m.in. poglądu Gottfrieda Wilhelma Leibniza, że świat, w jakim żyjemy, jest najdoskonalszym i najlepszym $z$ możliwych światów ${ }^{7}$. Wykpione zostało tu także przekonanie o zgodności wiary z rozumem ${ }^{8}$, wyrażone przez tego filozofa na kartach Teodycei, oraz sformułowane w Etyce nikomachejskiej przeświadczenie Arystotelesa regulujące zasady sprawiedliwości rozdzielczej (iustitia distributiva), zgodnie z którym sprawiedliwość społeczna polega m.in. na dystrybucji dóbr według zasług oraz propor-

6 Taką ujednoznaczniającą interpretacje proponuje Michalski (op. cit., s. 127).

7 G. W. Leib niz formułował to przekonanie wielokrotnie. Pojawia się ono choćby w nieukończonym dialogu Wyznanie wiary filozofa (w: Teodycea. O dobroci Boga, wolności człowieka i pochodzeniu zła. Przeł., przypisy M. Frankiewicz. Przekład przejrz., wstępem poprzedził J. Kopania. Warszawa 2001).

8 G. W. Leibniz, O zgodności wiary z rozumem. W: jw. 
cjonalnym rozdziale obowiązków ${ }^{9}$. Nie oszczędzono również Kartezjańskiego sformułowania: „zmysły nasze zwodzą nas niekiedy”, zaczerpniętej ze słynnej Rozprawy o metodzie francuskiego filozofa ${ }^{10}$, nadając tej maksymie paradoksalny, a przez to komiczny kształt: „nie można ślepo wierzyć własnym oczom. [...] to wielka ślepota wierzyć swoim oczom" (KS 125) ${ }^{11}$.

Ponadto $\mathrm{w}$ tekście Kołakowskiego łupem parodii pada koncepcja rozumienia czasu tożsama $z$ idea postępu. Za twórców tej koncepcji uznaje się Jeana Antoine’a Nicolasa de Condorceta oraz Anne'a Roberta Jacques'a Turgota, a w niej samej upatruje się wyraz oświeceniowego optymizmu i niezachwianej wiary w potęgę rozumu. Na marginesie warto dodać, że nieufność w stosunku do koncepcji tego typu nieobca była także Beckettowi, czego jeden $z$ wielu wymownych świadectw stanowi monolog wypowiedziany przez Lucky'ego, w którym bohater powtarza wielokrotnie i w różnych kontekstach frazę: „Człowiek [...] mimo postępu [...] marnieje i usycha" (BC 76). Analogicznie w tekście scenicznym polskiego filozofa informacje o zmienianiu się - $\mathrm{z}$ upływem czasu - zasad ustanawiania ładu na coraz doskonalsze idą $\mathrm{w}$ parze $\mathrm{z}$ wyraźnym pogorszeniem się sytuacji pacjentów. Parodystycznie sformułowany akt wiary w doskonalenie się kolejnych systemów zyskuje w utworze następujący kształt: „KAŻDY DENTYSTA JEST LEPSZY NIŻ POPRZEDNI” (KS 134). To przekonanie ma pomóc bohaterom „przejść przez życie $z$ ufnością [...] w sens i rację wszystkiego, z wiarą w sprawiedliwość, porządek i postęp” (KS 134). Rozpatrywane w tym świetle, Jensenowskie odniesienie frazy: „to najsprawiedliwszy z możliwych systemów" (KS 131), do różnych form ładu (zorganizowanego według nie tylko nietożsamych ze sobą, lecz także nierzadko wykluczających się zasad) przestaje jawić się jako sprzeczne z regułami logiki. „Czyż muszę dodawać” - pyta retorycznie duchowny - ,że zawiera się w tym i ta prawda, że każdy poprzedni dentysta też jest bardzo dobry?” (KS 134). Co istotne, wypowiadane przez księdza Jensena zdania typu: „świat zmierza ku lepszemu”, „sprawiedliwość zwycięża” (KS 128), „Świat się rozwija” (KS 131), z jednej strony wydają się rażąco nieadekwatne w stosunku do okoliczności zaprezentowanych w utworze, $\mathrm{z}$ drugiej - to dzięki takim hasłom bohaterowie nie wpadaja w panikę i rozpacz.

9 W utworze Koła k ow s ki e go reguły te znajdują swoją reprezentację w stwierdzeniu: „Najlepiej, żeby każdy wypełniał swój obowiązek, wtedy jest sprawiedliwość” (KS 127), a także: „A cóż to innego sprawiedliwość, jak nie zasada, żeby każdy miał to, na co zasłużył?” (KS 131).

R. D e s c art e s, Rozprawa o metodzie. Przeł. T. Żeleń s ki (B oy). Warszawa 1952, s. 52. W farsie Kołakowskiego ksiądz Jensen, aby zaprzeczyć realności i doświadczeniu oraz uspokoić pacjentów wpadających w panikę $\mathrm{w}$ związku $\mathrm{z}$ wiadomością o tym, że wyjście $\mathrm{z}$ gabinetu stomatologicznego jest tylko jedno i że nikt spośród tych, którzy weszli, nigdy nie wrócił, argumentuje w sposób następujący: „na świecie dzieje się wiele rzeczy, których nie widzimy, a które się jednak dzieją. Nasze oczy, moi państwo, nie są najpewniejszymi świadkami - wiele nieszczęść spada na ludzi przez to, że wierzą bezkrytycznie wszystkiemu, co widza, i tylko temu, co widza, a nie wnikają w istotę rzeczy. [...] Ot, pod nami, w podłodze, przechodzi teraz jakiś robaczek. My go nie widzimy, a jednak przechodzi. Tak samo i w tym wypadku: ludzie mogą [...] wychodzić, a my tego możemy wcale nie widzieć" (KS 125).

11 Na marginesie warto dodać, że predylekcja do wyzyskiwania komizmu słownego w utworach jest charakterystyczna dla obu autorów. W sztuce Czekając na Godota czytelnik natrafić może bowiem na zabawne sformułowania, które na pierwszy rzut oka jawią się jako wewnętrznie sprzeczne, choćby „próżni nie brakuje” (BC 99). Z kolei w Systemie księdza Jensena pojawiają się np. zwroty pleonastyczne - typu: „to jest ludzki człowiek” (KS 121). 
Wspomniane dzieła łączy także repetycyjność przejawiająca się na płaszczyźnie leksykalnej, czego przykładami mogą być: sformułowania z Czekając na Godota, typu „to samo” / "tout de même” / "all the same”; „następnego dnia” / „lendemain” / „next day”; frazy „Nawykliśmy już do tego” / „Nous en avons l'habitude” / „We're used to it”; "Jeszcze jeden dzień odwalony” / "Voilà encore une journée de tirée” / „Another day done with”; przysłówki: „znów”/,encore”/ „again” oraz „zawsze” /toujour"/,always". W tekście polskiego filozofa odpowiedniki tych sformułowań to choćby frazy: „to samo”, ,jak przyjdzie pańska kolej”, „następny pacjent”, lub zdania: „Czy będziemy czekali znów od początku?”, „W tej chwili z gabinetu rozlega się podobny jak poprzednie, krótki i głośny krzyk". Co istotne, słownictwo wskazujące na powtarzalność pojawia się w obu dziełach zarówno w wypowiedziach bohaterów, jak i w didaskaliach.

Trzeba podkreślić, że repetycyjność urasta do rangi jednej z najważniejszych zasad konstrukcyjnych każdego $z$ utworów. W obu powracają te same lub nieznacznie zmodyfikowane wątki, powielane są też gesty postaci. Powtarzalność kojarzona jest także przez obu autorów $\mathrm{z}$ następowaniem po sobie kolejnych generacji ${ }^{12}$. W farsie Kołakowskiego inspirowanej dziełem Irlandczyka pojawia się informacja, że trwające dziesiątki lat wyczekiwanie na wizytę stomatologiczną staje się udziałem wielu pokoleń pacjentów. Z kolei w tekście twórcy Końcówki świadectwem tego może być taki uogólniający passus:

Łez na świecie jest zawsze tyle samo. Gdy jeden przestaje płakać, drugi gdzie indziej zaczyna [...]. Nie narzekajmy więc na nasze czasy, nie ma w nich więcej nieszczęścia niż dawniej [...]. Ale i nie chwalmy ich sobie. $[\mathrm{BC} 64]^{13}$

Do cech wspólnych analizowanych tekstów należy również to, że za pośrednictwem zaprezentowanych w nich zdarzeń oraz w dysputach bohaterów kategoria oczekiwania podlega wielopłaszczyznowej problematyzacji. O ile jednak Vladimir i Estragon czekają na enigmatycznego Godota, o tyle postaci z farsy Kołakowskiego oczekuja na moment, w którym zostaną wezwane, nie wiedza jednak, kiedy to nastąpi, zastanawiają się też, co się stanie, gdy wyjdą $\mathrm{z}$ gabinetu. W pierwszym wypadku - jeśli czytelnik zdecyduje się ująć wieloznaczne sygnały tekstowe w ramy interpretacji ujednoznaczniającej - czekanie daje się odczytać jako teologicznie lub ateologicznie rozumiany adwent, czyli oczekiwanie na przyjście (które może okazać się klęska), pragnienie uobecnienia się nieobecnego, zwracanie się ku oddalonemu innemu, relacja bez relacji, wyrastająca $z$ wiary, że ponowne spotkanie kiedyś jeszcze nastąpi ${ }^{14}$. Czekanie będzie również wówczas jawić się albo jako koncentracja na tym, co niedokonane, albo jako bezczynność. Stanie się wtedy przyczyna zobojętnienia na to, co dzieje się tu i teraz (czego przykładem będzie brak reakcji

Ponadto u Becketta repetycyjność identyfikowana jest z rytmem natury. Przejawia się on biciem serca postaci, naprzemiennym następstwem dnia i nocy, wyznaczającym czas akcji, oraz cyklicznością pór roku.

13 Świadomość powtarzalności losu kolejnych generacji dochodzi do głosu także w stwierdzeniu Pozza: „któregoś dnia urodziliśmy się, któregoś dnia umrzemy, tego samego dnia, w tej samej chwili, nie wystarcza to panu? (Spokojniej) One rodzą okrakiem na grobie, światło świeci przez chwilę, a potem znów noc, znów noc [...]" (BC 125).

14 Zob. esej M. P. Markows kiego o adwencie jako oczekiwaniu na przyjście: Pour l'autre, pour moi. W: Występek. Eseje o pisaniui.czytaniu, Warszawa 2001, s. 199. 
Didi i Gogo na ponawiana przez Pozza prośbę o pomoc, pomimo świadomości bohaterów, że mogłaby ona być synekdochą ludzkiego wołania o ratunek). W tekście irlandzkiego autora synonimami oczekiwania bywają także doznanie tego, że „czas się dłuży” (BC 114), „spędzanie czasu” w sensie dosłownym (BC 43) ${ }^{15}$, czyli dążenie do tego, by „czas jakoś zleciał” (BC 81), „śmiertelna nuda” (BC 115), rodzaj „nawyku” 16 , „brak zdarzeń” (BC 74), inercja i bezczynność (BC 87, 130), nie kończąca się udręka (BC 84), bezradność ${ }^{17}$, dyspozycja metafizyczna oraz doświadczenie wspólnej niedoli ${ }^{18}$ dane śmiertelnikom przed obróceniem się w nicość.

Z kolei w utworze scenicznym, który wyszedł spod pióra polskiego filozofa, oczekiwanie skłania do spekulacji na temat tego, „, co jest po drugiej stronie” (KS 116); kojarzone bywa także ze stratą czasu (KS 117) i przymusem, identyfikowane $z$,wyczerpującym zajęciem” (KS 117) lub „zasługą”" (KS 133). Okazuje się też, że w zależności od nastawienia - można czekać „nieporządnie, głupio” (KS 118), „byle jak, aby zbyć, niechlujnie i niestarannie” (KS 117), albo robić to „Z zamiłowaniem, z ochotą, poświęcać się temu zajęciu, kochać je, oddawać mu się całą duszą" (KS 118). Ponadto czekanie wiąże się $z$ koniecznością mierzenia się $z$ tym, co nieprzewidywalne, ponieważ nigdy do końca nie wiadomo, kto, kiedy i według jakiego systemu zostanie wezwany. Wymaga to od bohaterów albo pogodzenia się z istniejącym stanem rzeczy, albo uzasadnienia takiej sytuacji, a w konsekwencji: uznania, że skoro każdy ma wejść do gabinetu w stosownym momencie, czyli wtedy, gdy przyjdzie jego kolej, to chwila, w której to nastapi, musi być tą właściwa.

Warto dodać, że u Becketta $\mathrm{z}$ oczekiwaniem wiążą się takie stany emocjonalne bohaterów, jak niepewność, zwątpienie, nadzieja (na odmianę lub na zbawienie) oraz możliwość jej utraty. U Kołakowskiego czekaniu towarzyszą - w zależności od usposobienia postaci - albo optymizm, albo irytacja. Gdy staje się jasne, że wyjście $z$ gabinetu jest tylko jedno i że nikt $z$ wchodzacych nie wraca, a ksiądz Jensen dopiero obmyśla nowe uzasadnienie tego stanu rzeczy, wspomniane uczucia ustępują miejsca albo bezradności, albo panice i lękowi przed nicością. Rzec by można, iż problematyzacja kategorii oczekiwania w obu utworach okazuje się do tego stopnia wszechstronna i wielopłaszczyznowa, że jeśli przejrzy się możliwe synonimy tego słowa - takie jak: „odkładać coś na później”, „pragnaçc”, „spodziewać się”, „wyczekiwać”, „przewidywać”, „wiązać nadzieje”, „wyglądać czegoś”, „spodziewać się”, „nastawiać się na coś”, „Zwlekać”, „ociagać sie”, , „działać na zwłoke”, , ,odraczać”, „wstrzymywać”, „nie kwapić się”, „przeciagać coś w czasie”, wreszcie „liczyć na coś” - to okaże się, że wszystkie $\mathrm{z}$ wymienionych znaczen zostały w analizowanych tekstach zaktualizowane.

Dosłowność spędzania czasu sygnalizowana jest za pośrednictwem frazeologizmu: „czas zejdzie” (BC 43).

Nawykowość opisywanej czynności wyrażona zostaje w tekście m.in. w postaci takich replik dialogowych:

ESTRAGON: Trzeba po prostu czekać. VLADIMIR: Nawykliśmy już do tego. [BC 70]

Opisywana wspólnota doświadczenia komunikowana jest np. zwrotem: „ramię w ramię czekają” (BC 61).

W myśl zasady: „każda zasługa jest policzona człowiekowi, [...] nie ma zasługi bez nagrody” (KS 133). 
Wspólnymi dla obu dzieł i ściśle związanymi z oczekiwaniem kategoriami temporalnymi są ponadto niedokonanie (współistniejące ze stawaniem się) oraz zmiana. W utworze Becketta brakuje panaceum na ten pierwszy typ doświadczenia czasu. Z kolei w farsie Kołakowskiego funkcję antidotum na sytuację, w której nie ziściło się coś, co powinno było zaistnieć, pełnią ponawiane co jakiś czas próby zaprowadzenia nowego porządku i ustanowienia sprawiedliwości. Bez względu na to, czy dana propozycja systemowa daży do wyeliminowania przypadku (KS 127), czy też bierze w rachubę ludzkie pomyłki (KS 131), szybko okazuje się jedynie pozornym remedium na bolączki opisane w utworze. Co istotne, bohaterowie sztuki Czekajac na Godota oraz Systemu księdza Jensena, z jednej strony doświadczają zmian, $z$ drugiej zaś - w specyficzny sposób zaprzeczają im, ponieważ nie chca uznać, że najważniejsze może być to, co dane tu i teraz. Przypisują walor istotności przede wszystkim oczekiwanym zdarzeniom, na ogół niepomni, że mają one charakter jedynie wyobrażeniowy i postulowany. W wypadku tak skonstruowanych postaci literackich to swoiste „wychylenie w przyszłość” częściej okazuje się utrapieniem wynikającym $\mathrm{z}$ niedokonania, zmieniającym się w udrękę związaną z tym, że nie nastąpiło jeszcze to, co powinno już dawno nastapić, niż ufnym otwarciem się na to, co nieznane, autentyczna gotowością na niewiadomą.

Tak jak wyczekiwanie na to, co powinno się zdarzyć, warunkuje w tekstach Becketta i Kołakowskiego kondycję bohaterów i w wielu sytuacjach redukuje ją do „nieustannie wytężonej intencji”, tak w analizowanych utworach linia demarkacyjna między teraźniejszością a przeszłością nie zawsze jest wyrazista. Choć Pozzo, bohater sztuki Czekając na Godota, opisując zmianę zachowania Lucky'ego na gorsze, zdecydowanie przeciwstawia je swojemu, nietrudno wskazać jego wypowiedzi, w których granice między tymi planami czasowymi ewidentnie się zacierają. Także inne postaci mają trudności z dokładnym lokalizowaniem zdarzeń w czasie lub nie chcą ich precyzyjnie określić w sensie temporalnym. Za przykład niech posłuży następująca replika dialogowa:

POZzo: Przecież on jest niemy.

$[\ldots]$

VLADIMIR: Niemy! Od kiedy?

POzzo (rozwścieczony nagle): Przestanie mnie pan wreszcie zamęczać tym przeklętym czasem? To obłędne! Kiedy! Kiedy! Któregoś dnia, nie wystarcza to panu, któregoś dnia, takiego jak inne, oniemiał, któregoś dnia ja oślepłem, któregoś dnia staniemy się głusi, któregoś dnia urodziliśmy się, któregoś dnia umrzemy, tego samego dnia, w tej samej chwili, nie wystarcza to panu? [BC 125]

W utworach Becketta bywa też, że przeszłe zdarzenia okazują się minione tylko pozornie, ponieważ wniknęły w psychikę postaci tak głęboko, że rzutują na to, co teraźniejsze, a w konsekwencji nie mogą się ostatecznie dokonać. Owo niedomknięcie poszczególnych wymiarów czasu wiąże się również z tym, że niektóre zajścia przypominają się bohaterom mimowolnie, zakłócając doświadczenie aktualne, inne zaś - pomimo tego, że są ważne dla teraźniejszości - toną w mrokach niepamięci. W ten sposób postaci, będąc w czasie, zarazem doznają swoistej utraty jego poczucia. W utworze System księdza Jensena jej znak stanowią repliki dialogowe takie jak następująca: 
$\mathrm{O}$ ile jednak w analizowanym dramacie Irlandczyka utrata poczucia czasu określana jest mianem ślepoty (BC 121), o tyle w utworze polskiego filozofa jawi się jako nieostrożność skutkująca czekaniem na coś, czego, być może, nie ma.

Przy okazji premiery przygotowanego na podstawie omawianej farsy Kołakowskiego spektaklu Wejście i wyjście w reżyserii Jerzego Markuszewskiego (15 XII 1961, Teatr Ateneum im. Stefana Jaracza w Warszawie) ${ }^{20}$ filozof udzielił wywiadu dla „Kuriera Polskiego”. Zapytany, dlaczego napisał „sztukę, a nie np. artykuł”, odpowiedział: „Bo wydawało mi się, że forma sceniczna lepiej nadaje się do ośmieszenia filozofii”21. Taki był główny cel eksperymentu ze spuścizną literacką Becketta, niekoniecznie zaś polemika $\mathrm{z}$ tym dramaturgiem, jak zapowiada fragment tytułu utworu polskiego autora. W toku lektury System księdza Jensena okazuje się więc nie pozbawiony ironii $^{22}$. Wprawdzie filozof nie potępiał w czambuł propozycji światopoglądowych, które pozwalały ich zwolennikom nie popaść w rozpacz za cenę podtrzymywania fundamentalnych złudzeń, jednak zawsze odnosił się do tego typu systemów z dużą dozą dystansu. Analogiczną funkcje jak w dramacie irlandzkiego autora stwierdzenie: „przyzwyczajenie wspaniale tłumi krzyki” (BC 126), w farsie Kołakowskiego pełnia konstrukcje filozoficzne przesycone optymizmem i oderwane od doświadczenia ${ }^{23}$.

Abstract

ŻANETA NALEWAJK University of Warszaw

\section{LESZEK KOLAKOWSKI'S EXPERIMENT WITH BECKETT}

The aim of the article is to present the mode in which the Polish philosopher and writer Leszek Kołakowski in his stage piece System księdza Jensena, albo Wejście i wyjście. Farsa w dwóch aktach naśladowana $z$ różnych autorów, nieoryginalna. Polemika optymistyczna z Beckettem (The System of Jensen the Priest, or Entry and Exit. Farce in Two Acts Imitated after Many Authors, Unoriginal), originally published in Dialogue no. 6, 1965, refers to the Irish author's literary creativity. Experimenting with it, the Polish writer quotes Beckett's most crucial temporal categories such as waiting, non-accomplishment, repetition, boredom, and change. The researcher also discusses the literary consequences of common to both writers predilection for parodying and/or travestying well known philosophers' views. She furthermore proves that the main aim of Kołakowski's experiment with Beckett's output was to deride such worldview proposals which are detached from experience and filled with optimism and belief in justice and progress, not a mere polemics with the author of Happy Days as signaled in the title of the stage piece in question.

Widzowie mogli oglądać zaledwie trzy przedstawienia. Po tym, jak w teatrze wizytę złożył A. Starewicz, sekretarz ds. propagandy w KC PZPR, sztuka została zdjęta $z$ afisza.

Zob. Leszek Kołakowski $w$ roli autora dramatycznego. „Kurier Polski” 1961, nr z 15 XII.

Jeśli można mówić tu o polemice, to jej ostrze wymierzone jest w utworze w polemistów Becketta, jakkolwiek Kołakowski nie odmawia im racji egzystencjalnych.

Za ilustrację tego poglądu niech posłuży następujący fragment tekstu:

DOKTOR I STARSZA PANI (podśpiewuja wesoło): Do dentysty, do dentysty! ( $w$ tej chwili z gabinetu rozlega się podobny jak poprzednie, krótki i głośny krzyk. Nikt go nie zauważył oprócz księdza, który drgnąt lekko i natychmiast na cały gtos podtrzymuje chór Doktora i Starszej Pani: do dentysty, do dentysty!).

EWA: Do dentysty, do dentysty! Andrzeju, gdybyś wiedział, jaka jestem szczęśliwa! (KS 135).

Znamienne, że bohaterowie B e cketta pytaja jak Estragon: „Może by tak uznać się za szczęśliwych?” (BC 99), a jednocześnie nie są zdolni do uwewnętrznienia łatwych pocieszeń. 